\title{
Renal failure in fulminant hepatic failure and terminal cirrhosis: a comparison between incidence, types, and prognosis
}

\author{
H RING-LARSEN, ${ }^{*}$ AND U PALAZZO \\ From the Division of Hepatology, Medical Department, A, Rigshospitalet, Copenhagen, Denmark
}

SUMMARY Forty patients with terminal cirrhosis and 40 patients with fulminant hepatic failureall consecutively admitted-were studied with regard to incidence, types, and prognosis of complicating renal insufficiency. Renal failure was considered present when the serum creatinine was $>0.20 \mathrm{mmol} / \mathrm{l}$. Of the patients with cirrhosis $26(65 \%)$ developed renal failure. In 15 the type was functional, in three due to acute tubular necrosis, and in eight indeterminable. Of the patients with fulminant hepatic failure $22(55 \%)$ had renal insufficiency; of these 13 had functional renal failure, five acute tubular necrosis, and in four the type was indeterminable. In both categories of patients, renal failure was equally frequent among patients with or without gastrointestinal bleeding and with or without ascites or diuretic therapy. The biochemical tests of liver function were similar in patients with or without renal failure in both categories. The mean renal blood flow in seven unselected patients with fulminant hepatic failure was reduced in the same order as previously observed in patients with cirrhosis. In terminal cirrhosis the mortality rate was $88 \%$ in the presence of renal failure, $71 \%$ in its absence $(\mathrm{P}>0.05)$, while the same figures in fulminant hepatic failure were $100 \%$ and $67 \%(\mathrm{P}<0.05)$. The incidence, relative frequency, and prognosis of renal failure were not different in the two conditions, indicating identical pathophysiological circumstances.

Renal failure is a frequent complication in advanced liver disease.$^{12}$ In cirrhosis, the kidney insufficiency is most often of functional nature and carries a poor prognosis. ${ }^{3}$ The pathogenetic mechanism seems to be reduction of the renal blood flow, the aetiology of which remains obscure. ${ }^{4-6}$ However, data on the relative frequency of different types of renal failure in terminal cirrhosis are scarce.

Fulminant hepatic failure may also be worsened by renal insufficiency. However, little is known about the frequency, nature, and prognosis of the renal damage in acute liver failure. ${ }^{78}$

The objective of the present study was to compare the incidence, types, and prognosis of renal failure in terminal cirrhosis and fulminant hepatic failure.

\section{Methods \\ PATIENTS \\ Forty patients with advanced cirrhosis and 40 patients with fulminant hepatic failure were studied, all con- ${ }^{*}$ Address for correspondence: Dr H Ring-Larsen, Division of Hepatology, Københavns Kommunes Hvidovre Hospital, University of Copenhagen, DK-2650 Hvidovre, Denmark. \\ Received for publication 28 January 1981}

secutively admitted to Rigshospitalet, Copenhagen. The mean age of the cirrhotic patients, 19 women and 21 men, was 51 years (range 25-71 years). Alcoholic cirrhosis was present in 20, idiopathic cirrhosis in 18 , and primary biliary cirrhosis in two. In the cases with fulminant hepatitis, comprising 23 women and 17 men, the mean age was 43 years (range 16-17 years). Viral hepatitis was assumed to be the cause in 29 , multiple exposure to halothane in eight, and toxic hepatitis possibly due to disulfiram in three patients.

The diagnoses were assessed by liver biopsy or necropsy in all cases. Patients with a history of renal disease were excluded from the study.

The patients were studied from the time they lapsed into hepatic coma grade III-IV - at which time current diuretic therapy was discontinued in virtually all cases - and during the subsequent days untildeath or recovery. Diureses, serum and urine creatinine, sodium, and potassium were recorded daily. Renal failure was defined as a serum creatinine concentration above $0.20 \mathrm{mmol} / \mathrm{l}$ not due to dehydration, which was avoided in all patients. Terminal azotaemiathat is, a rise in the serum creatinine concentration solely within the last 24 hours of life-which occurred 
Table 1 Clinical and biochemical data at time of coma III-IV on 26 patients with cirrhosis and serum creatinine $>0 \cdot 2 \mathrm{mmol} / \mathrm{l}$ during admission

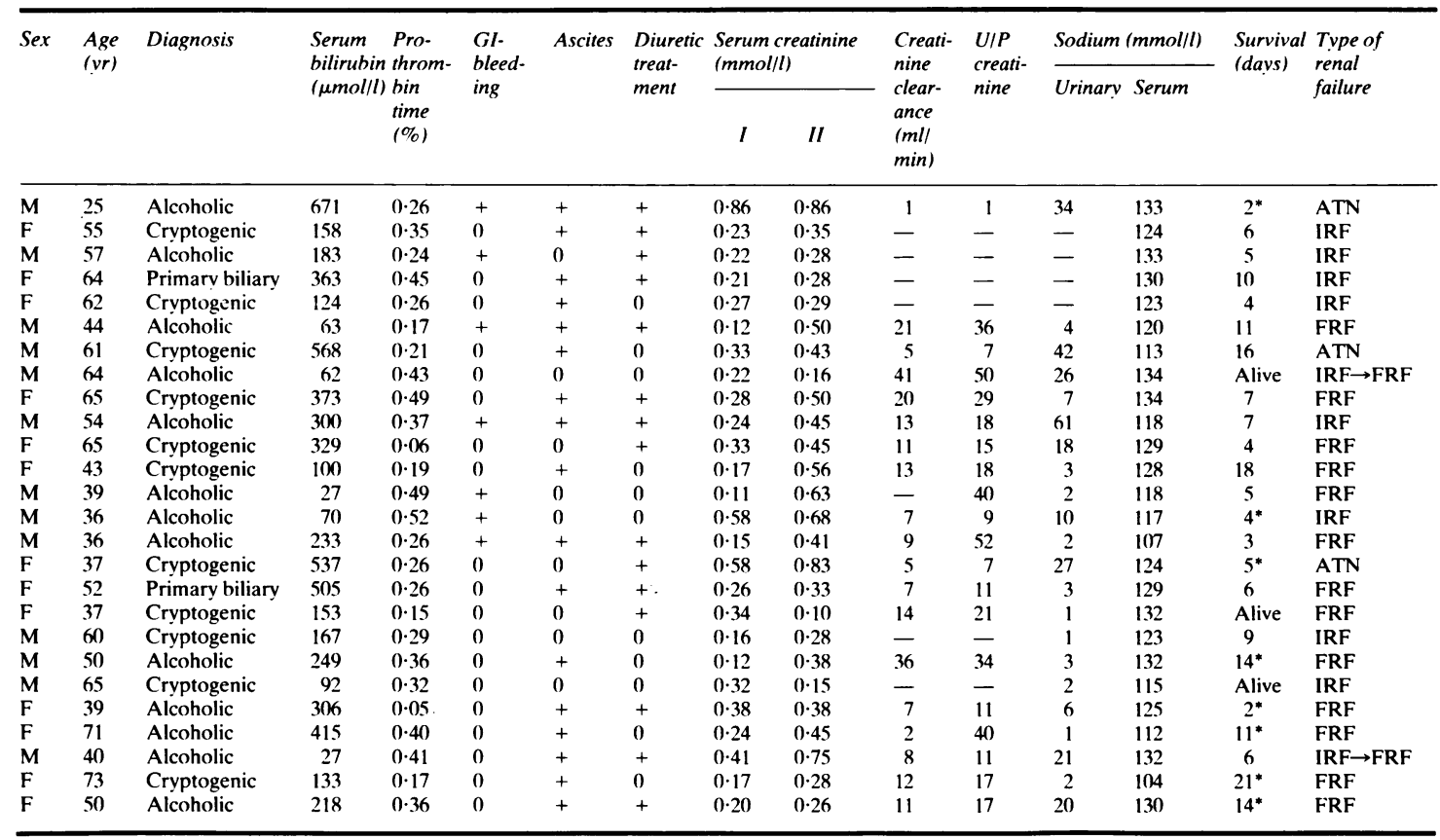

*Treated with peritoneal dialysis.

I At coma III-IV. II Before death or at discharge. ATN: acute tubular necrosis. FRF: functional renal failure. IRF: indeterminable renal failure.

in four of the cirrhotic patients and five of the patients with fulminant hepatitis, was not considered, as this is a frequent event in many diseases.

As a confident subdivision between the functional type of renal failure and acute tubular necrosis appears to be done at best on the basis of urinary sodium excretion and urine/plasma ratio of, for example, creatinine, ${ }^{9}$ the renal failure was categorised according to the following criteria.

\section{Acute tubular necrosis}

a. Urinary sodium concentration $>30 \mathrm{mmol} / \mathrm{l}$.

b. Urine /plasma creatinine ratio $<10$.

II Functional renal failure

a. Urinary sodium concentration $<10 \mathrm{mmol} / \mathrm{l}$ or if the patient received diuretics $<20 \mathrm{mmol} / \mathrm{l}$.

b. Urine/plasma creatinine ratio $>10$.

III Indeterminable renal failure

In some cases the data were contradictory or insufficient to place the type of renal failure in one of the above categories.

In seven unselected patients with fulminant hepatic failure with the mean age of 42 years the mean renal blood flow was determined at the time of exchange transfusion, during stable arterial blood pressure, by means of the ${ }^{133}$ Xenon wash-out method $^{10}$ as previously described." ${ }^{11}$ The kidney perfusion was compared with that of eight controls with a mean age of 31 years undergoing cardiac catheterisation for suspected but unconfirmed heart disease.

Statistical analysis was carried out by Fisher's exact test, Chi-square test, and Mann-Whitney rank sum test.

\section{Results}

\section{CIRRHOSIS}

Clinical and biochemical data on the patients with terminal cirrhosis are shown in Table 1 and 2 . At the time of coma renal failure was present in 18 patients, serum creatinine being mean $0.34 \mathrm{mmol} / \mathrm{l}$; an additional eight patients developed renal failure from two to 13 days thereafter. Three patients had acute tubular necrosis, 15 functional renal failure, while eight patients had renal failure which was indeterminable; in six cases this was because of insufficient data and in two because of data conflicting according to the criteria mentioned. Two of the patients with functional renal failure initially had indeterminable types but otherwise progression from one category to another did not take place.

Of 11 patients with gastrointestinal bleeding which could possibly have precipitated renal failure this 
Table 2 Clinical and biochemical data at time of coma III-IV on 14 patients with cirrhosis and serum creatinine $<0 \cdot 2$ mmolll during admission

\begin{tabular}{|c|c|c|c|c|c|c|c|c|c|c|}
\hline \multirow[t]{2}{*}{ Sex } & \multirow{2}{*}{$\begin{array}{l}\text { Age } \\
(y r)\end{array}$} & \multirow[t]{2}{*}{ Diagnosis } & \multirow{2}{*}{$\begin{array}{l}\text { Serum } \\
\text { bilirubin } \\
(\mu \mathrm{mol} / \mathrm{l})\end{array}$} & \multirow{2}{*}{$\begin{array}{l}\text { Prothrom- } \\
\text { bin time } \\
(\%)\end{array}$} & \multirow{2}{*}{$\begin{array}{l}\text { GI- } \\
\text { bleeding }\end{array}$} & \multirow[t]{2}{*}{ Ascites } & \multirow{2}{*}{$\begin{array}{l}\text { Diuretic } \\
\text { treatment }\end{array}$} & \multicolumn{2}{|c|}{ Sodium (mmoll/) } & \multirow{2}{*}{$\begin{array}{l}\text { Survival } \\
\text { (days) }\end{array}$} \\
\hline & & & & & & & & Urinary & Serum & \\
\hline$F$ & 50 & Alcoholic & 61 & 0.42 & 0 & 0 & 0 & - & 132 & Alive \\
\hline$F$ & 59 & Alcoholic & 110 & 0.41 & 0 & + & + & 34 & 132 & Alive \\
\hline $\mathbf{M}$ & 38 & Alcoholic & 45 & $0 \cdot 66$ & + & 0 & 0 & - & 144 & 17 \\
\hline $\mathbf{M}$ & 51 & Alcoholic & 39 & $0 \cdot 25$ & + & 0 & 0 & - & - & 2 \\
\hline $\mathrm{F}$ & 70 & Cryptogenic & 131 & $0 \cdot 28$ & 0 & 0 & 0 & - & 141 & 4 \\
\hline$F$ & 46 & Cryptogenic & 93 & $0 \cdot 33$ & 0 & + & + & 2 & 112 & 3 \\
\hline$F$ & 48 & Cryptogenic & 64 & $0 \cdot 28$ & 0 & + & 0 & 19 & 137 & 2 \\
\hline $\mathrm{F}$ & 52 & Cryptogenic & 371 & $0 \cdot 30$ & 0 & 0 & 0 & 22 & 140 & 2 \\
\hline M & 46 & Cryptogenic & 58 & 0.36 & 0 & + & + & 6 & 127 & Alive \\
\hline M & 53 & Alcoholic & 37 & $0 \cdot 58$ & 0 & + & + & 4 & 129 & 5 \\
\hline $\mathbf{M}$ & 65 & Alcoholic & 249 & $0 \cdot 33$ & + & + & 0 & 9 & 141 & 4 \\
\hline M & 55 & Cryptogenic & 741 & $0 \cdot 35$ & 0 & + & 0 & 25 & 134 & 8 \\
\hline M & 54 & Alcoholic & - & $0 \cdot 36$ & + & + & 0 & - & 129 & 3 \\
\hline $\mathbf{M}$ & 51 & Cryptogenic & 135 & $0 \cdot 38$ & 0 & + & + & 2 & 135 & Alive \\
\hline
\end{tabular}

occurred in seven, while among 29 patients without bleeding renal failure was present in $19(\mathrm{p}>0 \cdot 20)$. Of the seven patients with renal failure and preceding gastrointestinal bleeding three had functional renal failure, one acute tubular necrosis, and three the indeterminable type of renal failure.

Renal failure was equally frequent in patients with and without ascites, 17 of 26 and nine of 14 respectively $(\mathrm{P}>0 \cdot 20)$. However, among the 15 patients with functional renal failure only two were without clinical signs of sodium and water retention or without diuretic therapy to prevent recurrence of ascites. However, diuretic therapy-before coma III-IVwas not associated with any significant increase in the frequency of renal failure. Of 15 patients receiving diuretic treatment before lapsing into hepatic coma the renal function improved in one, while in the others it remained unchanged or progressed, as judged by a further increase in serum creatinine, even though diuretics had been discontinued.

The serum sodium concentration was significantly lower in patients with renal failure than in patients with normal kidney function (mean values 128 and $133 \mathrm{mmol} / \mathrm{l}, \mathrm{P}<0 \cdot 05$ ). Among the patients with renal failure the mean serum sodium concentration was 131 $\mathrm{mmol} / \mathrm{l}$ in patients without ascites, $129 \mathrm{mmol} / \mathrm{l}$ in the presence of ascites, and $119 \mathrm{mmol} / \mathrm{l}$ in those on diuretic therapy.

The biochemical tests of liver function showed no difference between patients with and without renal failure. Only three patients with renal failure $(12 \%)$ survived the acute exacerbation and were discharged, while four $(29 \%)$ of the patients without this complication survived $(\mathrm{P}>\mathbf{0} \cdot 20)$. All patients with gastrointestinal bleeding died. When patients with this complication were excluded, the mortality rate of the patients with or without renal failure was 84 and $60 \%$ respectively $(\mathrm{P}>0 \cdot 20)$. Peritoneal dialysis was carried out in eight patients and, although this treatment complemented renal function as judged by the fall in serum creatinine, none of the patients survived.

\section{FULMINANT HEPATIC FAILURE}

Clinical and biochemical data on the patients with fulminant hepatic failure are shown in Tables 3 and 4 .

At the time of coma, renal failure was present in 15 patients, serum creatinine being mean $0.53 \mathrm{mmol} / \mathrm{l}$. Another seven patients developed renal failure from two to eight days thereafter. Five patients had acute tubular necrosis, 13 functional renal failure, while four patients had renal failure which was indeterminable - in two cases because of insufficient data and in two because of data conflicting according to the criteria mentioned. Of three patients with initially indeterminable type the renal failure turned out to be functional in one and due to acute tubular necrosis in two. In none of the cases could the therapeutic procedures be considered as likely aetiological factors of renal failure.

Renal failure was more frequent among patients who had bled from the gastrointestinal tract. Of 10 patients with this complication, renal failure occurred in eight, while, of 30 patients without gastrointestinal bleeding, renal failure occurred in 14. However, the difference was statistically insignificant $(0 \cdot 20>\mathrm{P}>0 \cdot 10)$. Of the eight patients with gastrointestinal bleeding and renal failure seven had functional renal failure and one acute tubular necrosis.

Renal failure was more frequent in the presence of ascites but the difference was insignificant: nine of 11 and 13 of 29 respectively $(0 \cdot 10>p>0 \cdot 05)$. Unlike the findings in cirrhotic patients, of the 13 patients with functional renal failure only four had ascites. Diuretic therapy was not associated with any increase in the frequency of renal failure. The renal function did not 
Table 3 Clinical and biochemical data at time of coma III-IV on 22 patients with fulminant hepatic failure with serum creatinine $>0.2 \mathrm{mmol} / \mathrm{l}$ during admission

\begin{tabular}{|c|c|c|c|c|c|c|c|c|c|c|c|c|c|c|c|c|}
\hline \multirow{3}{*}{ Sex } & \multirow{3}{*}{$\begin{array}{l}\text { Age } \\
\text { (yr) }\end{array}$} & \multirow{3}{*}{ Diagnosis } & \multirow{3}{*}{$\begin{array}{l}\text { Serum } \\
\text { hilirubin } \\
\text { 'pmol/l) }\end{array}$} & \multirow{3}{*}{$\begin{array}{l}\text { Pro- } \\
\text { throm- } \\
\text { bin } \\
\text { time } \\
(\%)\end{array}$} & \multirow{3}{*}{$\begin{array}{l}\text { GI- } \\
\text { bleed- } \\
\text { ing }\end{array}$} & \multirow{3}{*}{ Ascites } & \multirow{3}{*}{$\begin{array}{l}\text { Diuretic } \\
\text { treat- } \\
\text { ment }\end{array}$} & \multirow{2}{*}{\multicolumn{2}{|c|}{$\begin{array}{l}\text { Serum creatinine } \\
(\mathrm{mmol} / \mathrm{l})\end{array}$}} & \multirow{3}{*}{$\begin{array}{l}\text { Creati- } \\
\text { nine } \\
\text { clear- } \\
\text { ance } \\
(\mathrm{ml} / \\
\mathrm{min})\end{array}$} & \multirow{3}{*}{$\begin{array}{l}U / P \\
\text { creati- } \\
\text { nine }\end{array}$} & \multicolumn{2}{|c|}{ Sodium (mmol/l) } & \multirow{3}{*}{$\begin{array}{l}\text { Sur. } \\
\text { vival } t \\
\text { (davs) }\end{array}$} & \multirow{3}{*}{$\begin{array}{l}\text { Specific } \\
\text { treatment }\end{array}$} & \multirow{3}{*}{$\begin{array}{l}\text { Type of } \\
\text { renal } \\
\text { failure }\end{array}$} \\
\hline & & & & & & & & & & & & Urinary & Serum & & & \\
\hline & & & & & & & & $I$ & II & & & & & & & \\
\hline $\mathrm{F}$ & 73 & Toxic & 461 & $0 \cdot 19$ & 0 & + & + & $0 \cdot 18$ & 0.32 & - & - & 8 & 109 & 14 & \multirow{2}{*}{$\begin{array}{l}\text { Exch. transf. } \\
\text { Peritoneal dialysis } \\
\text { Exch. transf. }\end{array}$} & IRF \\
\hline $\mathrm{F}$ & 55 & Halothane & 450 & $0 \cdot 36$ & 0 & + & + & $0 \cdot 80$ & 0.74 & 1 & 4 & 1 & 127 & 18 & & $\mathrm{IRF} \rightarrow \mathrm{ATN}$ \\
\hline $\mathbf{M}$ & 47 & Viral & 837 & $0 \cdot 19$ & 0 & + & + & $0 \cdot 36$ & $0 \cdot 28$ & 8 & 16 & 9 & 134 & 4 & Exch. transf. & FRF \\
\hline $\mathrm{F}$ & 76 & Viral & 684 & $0 \cdot 20$ & 0 & 0 & 0 & $0 \cdot 63$ & $1 \cdot 01$ & 0 & 24 & 2 & 139 & 13 & $\begin{array}{l}\text { Peritoneal dialysis } \\
\text { Exch. transf. }\end{array}$ & FRF \\
\hline $\mathbf{M}$ & 42 & Halothane & 274 & $0 \cdot 12$ & 0 & + & 0 & $0 \cdot 23$ & $0 \cdot 17$ & 2 & 23 & 5 & 122 & 13 & $\begin{array}{l}\text { Peritoneal dialysis } \\
\text { Exch. transf. }\end{array}$ & FRF \\
\hline $\mathrm{F}$ & 55 & Viral & 462 & $0 \cdot 06$ & 0 & + & 0 & $0 \cdot 14$ & 0.57 & - & 39 & 1 & 123 & 12 & $\begin{array}{l}\text { Peritoneal dialysis } \\
\text { Exch. transf. }\end{array}$ & FRF \\
\hline $\mathbf{M}$ & 42 & Toxic & 564 & $0 \cdot 15$ & + & + & 0 & $0 \cdot 60$ & 0.56 & 9 & 10 & 16 & 128 & 6 & $\begin{array}{l}\text { Peritoneal dialysis } \\
\text { Exch. transf. }\end{array}$ & $\mathrm{IRF} \rightarrow \mathrm{FRF}$ \\
\hline M & 63 & Viral & 325 & $0 \cdot 07$ & + & 0 & 0 & $0 \cdot 25$ & 0.54 & 16 & 30 & 5 & 127 & 6 & Exch. transf. & FRF \\
\hline $\mathbf{M}$ & 64 & Viral & - & $0 \cdot 05$ & + & 0 & 0 & $0 \cdot 41$ & $0 \cdot 63$ & $<1$ & 24 & 7 & 146 & 7 & Exch. transf. & FRF \\
\hline $\mathrm{F}$ & 24 & Viral & 83 & $0 \cdot 03$ & 0 & 0 & 0 & $0 \cdot 24$ & $0 \cdot 29$ & 4 & 30 & 8 & 145 & 3 & Exch. transf. & FRF \\
\hline $\mathrm{F}$ & 52 & Viral & 592 & $0 \cdot 10$ & 0 & 0 & $*$ & $0 \cdot 10$ & 0.95 & 20 & 33 & 2 & 133 & 14 & $\begin{array}{l}\text { Pig liver perf. } \\
\text { Exch. transf. }\end{array}$ & FRF \\
\hline$F$ & 20 & Viral & 194 & $0 \cdot 11$ & + & 0 & 0 & $0 \cdot 84$ & $1 \cdot 00$ & $<1$ & 9 & 31 & 137 & 3 & Exch. transf. & ATN \\
\hline $\mathbf{M}$ & 21 & Viral & 318 & $0 \cdot 05$ & + & 0 & 0 & $0 \cdot 19$ & $0 \cdot 12$ & - & 73 & 8 & 137 & 4 & Exch. transf. & FRF \\
\hline $\mathrm{F}$ & 70 & Viral & 628 & $0 \cdot 27$ & + & 0 & 0 & $0 \cdot 52$ & 0.52 & 1 & 28 & 51 & 120 & 15 & Peritoneal dialysis & $\mathrm{IRF} \rightarrow \mathrm{ATN}$ \\
\hline $\mathrm{F}^{*}$ & 61 & Viral & 308 & $0 \cdot 28$ & 0 & + & + & $0 \cdot 86$ & 0.57 & 1 & 5 & 29 & 115 & 7 & Peritoneal dialysis & ATN \\
\hline $\mathrm{F}^{*}$ & 53 & Halothane & 419 & $0 \cdot 05$ & 0 & 0 & 0 & $0 \cdot 08$ & $0 \cdot 28$ & - & 60 & 30 & 127 & 6 & Exch. transf. & IRF \\
\hline $\mathrm{F}$ & 51 & Halothane & 549 & $0 \cdot 14$ & + & 0 & 0 & 0.62 & $0 \cdot 84$ & 7 & 11 & 9 & 131 & 6 & & FRF \\
\hline $\mathbf{M}$ & 59 & Viral & 404 & 0.05 & 0 & 0 & 0 & $0 \cdot 09$ & 0.41 & - & - & 12 & 141 & 5 & & FRF \\
\hline M & 54 & Viral & 273 & 0.07 & 0 & + & 0 & 0.44 & 0.49 & 3 & 18 & 23 & 130 & 2 & Peritoneal dialysis & IRF \\
\hline $\mathbf{M}^{*}$ & 50 & Viral & 347 & $0 \cdot 15$ & 0 & + & 0 & 0.95 & $0 \cdot 49$ & 2 & 2 & 33 & 120 & 17 & $\begin{array}{l}\text { Exch. transf. } \\
\text { Pig liver perf. }\end{array}$ & ATN \\
\hline $\mathbf{F}$ & 42 & Halothane & 279 & $0 \cdot 03$ & + & 0 & 0 & $0 \cdot 06$ & $0 \cdot 36$ & - & 25 & 3 & 130 & 8 & Exch. transf. & FRF \\
\hline F & 60 & Toxic & 305 & $0 \cdot 10$ & 0 & 0 & 0 & $0 \cdot 09$ & $0 \cdot 38$ & - & 33 & 1 & 124 & 15 & $\begin{array}{l}\text { Peritoneal dialysis } \\
\text { Exch. transf. }\end{array}$ & FRF \\
\hline
\end{tabular}

* Renal blood flow: see Figure.

I At coma III-IV. II Before death. ATN: acute tubular necrosis. FRF: functional renal failure. IRF: indeterminable renal failure.

Table 4 Clinical and biochemical data at time of coma III-IV on 18 patients with fulminant hepatic failure with serum creatinine $<0 \cdot 2$ mmol/l during admission

\begin{tabular}{|c|c|c|c|c|c|c|c|c|c|c|c|}
\hline \multirow[t]{2}{*}{ Sex } & \multirow{2}{*}{$\begin{array}{l}\text { Age } \\
(y r)\end{array}$} & \multirow[t]{2}{*}{ Diagnosis } & \multirow{2}{*}{ 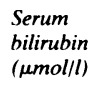 } & \multirow{2}{*}{$\begin{array}{l}\text { Prothrom- } \\
\text { bin time } \\
(\%)\end{array}$} & \multirow{2}{*}{$\begin{array}{l}\text { GI- } \\
\text { bleeding }\end{array}$} & \multirow[t]{2}{*}{ Ascites } & \multirow{2}{*}{$\begin{array}{l}\text { Diuretic } \\
\text { treatment }\end{array}$} & \multicolumn{2}{|c|}{ Sodium (mmol/l) } & \multirow{2}{*}{$\begin{array}{l}\text { Survival } \\
\text { (days) }\end{array}$} & \multirow{2}{*}{$\begin{array}{l}\text { Specific } \\
\text { treatment }\end{array}$} \\
\hline & & & & & & & & Urinary & Serum & & \\
\hline$F$ & 40 & Viral & 487 & 0.08 & 0 & 0 & 0 & - & 134 & 4 & \multirow[t]{2}{*}{ Exch. transf. } \\
\hline M & 22 & Halothane & 551 & $0 \cdot 10$ & 0 & 0 & 0 & 6 & 131 & 4 & \\
\hline$F$ & 27 & Viral & 284 & $0 \cdot 18$ & 0 & 0 & 0 & 5 & 137 & 11 & \multirow{5}{*}{$\begin{array}{l}\text { Pig liver perf. } \\
\text { Exch. transf. } \\
\text { Exch. transf. } \\
\text { Exch. transf. } \\
\text { Exch. transf. } \\
\text { Exch. transf. } \\
\text { Pig liver perf }\end{array}$} \\
\hline$F$ & 24 & Viral & 275 & $0 \cdot 24$ & 0 & 0 & 0 & 13 & 136 & Alive & \\
\hline M & 44 & Viral & 330 & 0.09 & 0 & 0 & 0 & 34 & 139 & Alive & \\
\hline $\mathbf{M}$ & 46 & Halothane & 190 & $0 \cdot 13$ & 0 & 0 & 0 & 42 & 145 & Alive & \\
\hline $\mathbf{M}$ & 25 & Viral & 196 & $0 \cdot 15$ & 0 & 0 & 0 & 1 & 140 & Alive & \\
\hline$F$ & 47 & Halothane & 266 & $0 \cdot 10$ & 0 & 0 & 0 & 5 & 133 & 8 & Exch. transf. \\
\hline $\mathrm{F}$ & 33 & Viral & 672 & 0.14 & 0 & 0 & 0 & 4 & 142 & 5 & Exch. transf. \\
\hline $\mathbf{M}^{*}$ & 21 & Viral & 398 & $0 \cdot 14$ & 0 & 0 & 0 & 1 & 135 & 2 & Exch. transf. \\
\hline $\mathrm{F}$ & 41 & Viral & 618 & $0 \cdot 19$ & 0 & + & 0 & 25 & 118 & 8 & Exch. transf. \\
\hline $\mathrm{F}$ & 27 & Viral & 676 & 0.05 & 0 & 0 & + & 35 & 132 & 3 & Exch. transf. \\
\hline $\mathrm{F}^{*}$ & 16 & Viral & 690 & $0 \cdot 12$ & 0 & 0 & 0 & 16 & 136 & 15 & Exch. transf. \\
\hline $\mathrm{F}^{*}$ & 22 & Viral & 357 & 0.03 & 0 & 0 & 0 & 9 & 138 & 3 & \\
\hline $\mathbf{M}$ & 46 & Viral & 245 & $0 \cdot 13$ & + & 0 & 0 & 25 & 150 & 2 & \\
\hline $\mathbf{M}$ & 27 & Viral & 68 & $0 \cdot 27$ & 0 & + & + & 3 & 139 & Alive & \\
\hline$F^{*}$ & 32 & Viral & 490 & 0.09 & + & 0 & 0 & - & 140 & 4 & $\begin{array}{l}\text { Pig liver perf. } \\
\text { Exch. transf. }\end{array}$ \\
\hline $\mathbf{M}$ & 44 & Viral & 374 & $0 \cdot 11$ & 0 & 0 & 0 & - & 136 & Alive & \\
\hline
\end{tabular}

*Renal blood flow: see Figure. 
improve in relation to discontinuing diuretics in the four patients receiving this treatment before lapsing into hepatic coma.

The serum sodium concentration was significantly $(\mathrm{P}<0.05)$ lower in patients with renal failure than in patients with normal kidney function (mean values 129 and $137 \mathrm{mmol} / \mathrm{l})$. Among the patients with renal failure the mean serum sodium concentration was $134 \mathrm{mmol} / \mathrm{l}$ in those without ascites, $124 \mathrm{mmol} / \mathrm{l}$ in patients with this complication, and $121 \mathrm{mmol} / \mathrm{l}$ in those treated with diuretics.

The biochemical tests of liver function showed no difference between patients with or without renal failure.

None of the patients with renal failure survived, while six of the patients without this complication were discharged $(\mathrm{P}<0 \cdot 02)$. When patients with gastrointestinal bleeding were excluded, the mortality rate of the patients without renal failure was $56 \%$. Nine patients with considerably raised serum creatinine in whom there was sufficient time for therapy were treated by peritoneal dialysis. Judged by the laboratory data this treatment was effective, but it did not influence the survival rate.

In seven unselected patients with fulminant hepatic failure, the mean renal blood flow was $1.40 \mathrm{ml} / \mathrm{g} / \mathrm{min}$ compared with $3.34 \mathrm{ml} / \mathrm{g} / \mathrm{min}$ in eight controls $(\mathrm{P}<0 \cdot 05)$ (Figure).

\section{COMPARISON}

The incidence and relative frequency of different types of renal insufficiency were not different in terminal cirrhosis and fulminant hepatic failure. The prognosis in the case of renal failure was not significantly different in the two groups.

\section{Discussion}

The present results assess the high incidence of renal failure in terminal cirrhosis and confirm the clinical impression of renal failure as a traditional complication in fulminant hepatic failure. Moreover, the results establish a similarity in the relative frequency of different types of renal insufficiency, in prognosis, and in pattern of renal hypoperfusion in the two groups of patients.

The frequency of renal failure in cirrhosis depends on the stage of the disease and the criteria used for defining the condition. However, terminally in the disease the incidence seems to be about $75 \%^{12-14}$

The frequency of complicating renal failure in fulminant hepatic failure cannot be readily assessed. ${ }^{1516}$ The present incidence of $55 \%$ is significantly less than that of 79 observed by Wilkinson et al. ${ }^{8}$ in a comparable study. Several reasons could account for the discrepancy. In the present study the upper limit for serum creatinine concentration was higher than that of $0.18 \mathrm{mmol} / \mathrm{l}$ used by Wilkinson et al. ${ }^{8}$ terminal azotaemia was not included, and paracetamol intoxication, which can possibly be a specific cause of renal damage, ${ }^{17}$ was absent.

Even when renal histology is available, the differentiation between functional renal failure and acute tubular necrosis may be difficult, as post mortem kidney microscopy is generally hard to evaluate ${ }^{18}$ and as 'acute tubular necrosis', despite the terminology, may present itself with extremely minute pathological changes similar to those in functional renal failure. ${ }^{19}$ Casts in the urine sediment are likewise of limited value, as this is not an obligatory finding in acute tubular necrosis and as hyaline and granular casts in the urine are often present in advanced liver disease unrelated to impairment of renal function. ${ }^{20}$

$$
\mathrm{ml} \cdot \mathrm{g}^{-1} \cdot \mathrm{min}^{-1}
$$

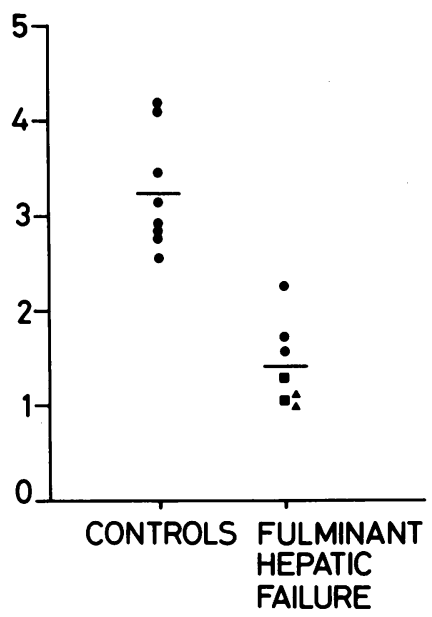

Figure Mean renal blood flow in eight healthy control subjects and seven patients with fulminant hepatic failure. patients with acute tubular necrosis. $\Delta$ patients with functional renal failure.

At present, the differentiation between functional renal failure and other types of renal failure occurring in liver disease rests on few criteria-namely, urine sodium concentration, kidney concentration ability, and response to volume expansion. ${ }^{9}$ It has been suggested that the difference between the two types of renal insufficiency in liver disease may be quantitative rather than qualitative, in that tubular function appears to be maintained until renal perfusion decreases to a degree where tubular necrosis occur. ${ }^{21}$ Such a progression appeared to be surprisingly un- 
common in both categories of patients in the present study.

The relative frequency of different types of renal failure in terminal cirrhosis is unknown. In a prospective study of 15 patients with cirrhosis and renal failure Shear et al. ${ }^{22}$ found indications of acute tubular necrosis in eight. The diagnoses were, however, partly based on urine sediment and a suspicion of precipitating events. Moreover, in several of these patients, specific gravity of the urine was higher and urine sodium concentration lower than would be expected in acute tubular necrosis.

The relative frequency of different types of renal insufficiency in fulminant hepatic failure was studied by Mas et al. ${ }^{16}$ who found acute tubular necrosis in two of six patients, the rest having functional renal failure. Wilkinson et al. ${ }^{8}$ on the other hand, reported acute tubular necrosis in the majority of patients with renal failure in the course of fulminant hepatic failure. This contrast with the present results is not readily explained, except perhaps by the great number of paracetamol poisonings among their patients.

Gastrointestinal bleeding and forced diuresis may cause renal failure of both types in cirrhosis as well as fulminant hepatic failure. ${ }^{72-24}$ Such a trend was observed in the present study but did not turn out to be statistically significant, confirming that functional renal failure in hepatic insufficiency most often occurs without any precipitating events. Ascites, which has been regarded an integral part of the clinical picture in functional renal failure in advanced liver disease, ${ }^{18}$ was absent in one-third of the patients with terminal cirrhosis and in most patients with fulminant hepatic failure, which indicates that portal hypertension is perhaps not a prerequisite for functional renal failure in either condition.

Mean renal blood flow in patients with fulminant hepatic failure apparently equals that of noncomatose cirrhotic patients with azotaemia. ${ }^{6}$ This finding indicates that identical pathophysiological circumstances may be present in terminal cirrhosis and fulminant hepatic failure..$^{25}$

It is widely considered that the mortality in renal failure in cirrhosis is close to $100 \%,{ }^{22} 2627$ and that spontaneous recovery is exceptional. ${ }^{28}$ An equally high mortality rate has been observed in fulminant hepatic failure but, unlike what is seen in cirrhotic patients, without any apparent difference between patients with or without renal failure. ${ }^{16}$ However, such a difference was significant in the present study. Results from peritoneal dialysis in cirrhosis have been disappointing, ${ }^{29}$ but an uncontrolled study of this treatment in fulminant hepatic failure complicated with renal insufficiency did improve survival. ${ }^{30}$ Such optimism cannot be supported by the present data.
The importance of concomitant renal failure in severe liver disease as being a determinant of the poor prognosis is difficult to evaluate. It is probably correct to consider that the vasoconstriction in the kidneys leading to renal failure-in cirrhosis as well as in fulminant hepatic failure-is part of an extensive lethal event that includes haemodynamic collapse in the progressive course of hepatic insufficiency, the latter determing the outcome of the disease. However, whether the renal hypoperfusion is primaryfor example, caused by agents with vasoconstrictor properties ${ }^{31-34}$ - or secondary to decreased systemic vascular resistance remains to be resolved. Recent studies may indicate that the latter hypothesis is correct. ${ }^{35}$

\section{References}

'Conn HO. A rational approach to the hepatorenal syndrome. Gastroenterology 1973; 65: 321-40.

${ }^{2}$ Papper S. Renal failure in cirrhosis (the hepatorenal syndrome). In: Epstein M, ed. The kidney in liver disease New York: Elsevier, 1978: 91-112.

${ }^{3}$ Baldus WF, Feichter RN, Summerskill WH. The kidney in cirrhosis. I. Clinical and biochemical features of azotemia in hepatic failure. Ann Intern Med 1964; 60: 353-65.

${ }^{4}$ Epstein M, Berk DP, Hollenberg NK, et al. Renal failure in patients with cirrhosis. Am J Med 1970; 49: 1175-87.

${ }^{5}$ Kew MC, Varma RR, Williams HS, Brunt PW. Hourigan KJ, Sherlock S. Renal and intrarenal blood flow in cirrhosis of the liver. Lancet 1971; 2: 504-9.

${ }^{6} \mathrm{Ring}$-Larsen H. Renal blood flow in cirrhosis: Relation to systemic and portal haemodynamics and liver function. Scand J Clin Lab Invest 1977; 37: 635-42.

${ }^{7}$ Hecker R, Sherlock S. Electrolyte and circulatory changes in terminal liver failure. Lancet 1956; 2: 1121-25.

${ }^{8}$ Wilkinson SP, Blendis LM, Williams R. Frequency and type of renal failure and electrolyte disorders in fulminant hepatic failure. Br Med J 1974; 1: 186-89.

${ }^{9}$ Early L. Summary and conclusions of round table-Presentation of diagnostic criteria. In: Bartoli E, Chiandussi L, eds. Hepato-renal syndrome. Padova: Piccin Medical Books, 1979; 493-501.

${ }^{10}$ Ladefoged $\mathrm{J}$. Measurements of the renal blood flow in man with the ${ }^{133}$ Xenon wash-out technique. Scand J Clin Lab Invest 1966; 18: 299-315.

"Ring-Larsen H, Hesse B, Stigsby B. Effect of portalsystemic anastomosis on renal haemodynamics in cirrhosis. Gut 1976; 17: 856-60.

${ }^{12}$ Clermont RJ, Zdravko RV, Chalmers TC, Adham NF, Curtis GW, Morrison RS. Intravenous therapy of massive ascites in patients with cirrhosis. II. Long term effects on survival and frequency of renal failure. Gastroenterology 1967; 53: 220-28.

${ }^{13}$ Shimp W. Hepatorenal syndrome. Minn Med 1975; 58: 479-85.

${ }^{14}$ Thomsen AC, Juhl E. Renal failure in terminal cirrhosis of the liver. Scand J Gastroenterol suppl 1970; 7: 117-21.

${ }^{15}$ Ritt DJ, Whelan G, Werner DJ, Eugenbrodt EH, 
Schenker S, Combes B. Acute hepatic necrosis with stupor or coma. Medicine 1969; 48: 151-72.

${ }^{16} \mathrm{Mas} \mathrm{A}$, Bosch J, Rodes J, et al. Insufficiencia renal en la hepatitis fulminante. Rev Clin Esp 1974; 133: 423.

${ }^{17}$ Matthews H. Drug overdose. Medicine (London) 1972; 4: 273-86.

${ }^{18} \mathrm{de}$ Wardener HE. The kidney. An outline of normal and abnormal structure and function Edinburgh: Churchill Livingstone, 1973: 163-9.

${ }^{19}$ Brun C. Acute anuria. Copenhagen: Munksgaard, 1954: 102-18.

${ }^{20}$ Eknoyan G. Renal disorders in hepatic failure. Br Med J 1974; 2: 670

${ }^{21}$ Cachara R, Darnis F. Les formes inapparentes de l'oedeme dans l'infectieuse aiguë benigne hepatite. Sem Hôp Paris 1951; 27: 1843-9.

${ }^{22}$ Shear L, Kleinerman J, Gabuzda GJ. Renal failure in patients with cirrhosis. I. Clinical and pathologic characteristics. Am J Med 1965; 39: 184-98.

${ }^{23}$ Pequinot G, Pequinot E, Caroli E. Effets toxic retardes après traitement d'ascites cirrhotique par la cholorothiazide. Sem Hôp Paris 1960; 36: 1801-8.

${ }^{24}$ Bosch J, Arroyo V, Rodes J, Teres J, Bordas JM, Bruquera M. Insufficiencia renal inducida por diuréticos en la cirrosis hepática con ascitis. Rev Clin Esp 1973; 131: 375-82.

${ }^{25}$ Ring-Larsen $\mathrm{H}$, T $\phi$ nnesen $\mathrm{K}$, Holm-Bentzen $\mathrm{M}$, Christiansen LA. Renal and cerebral blood flow in experimental liver failure in the pig. Scand J Gastroenterol 1979; 14: 91-6.

${ }^{26}$ Papper S, Belsky JL, Bleifer KH. Renal failure in Laennec's cirrhosis of the liver. I. Description of clinical and laboratory features. Ann Intern Med 1959; 51:759-73.

${ }^{27}$ Lieberman FL, Reynolds TB. Renal failure with cirrhosis. Observation on the role of diuretics. Ann Intern Med 1966; 64: 1221-8.

${ }^{28}$ Goldstein H, Boyle JD. Spontaneous recovery from the hepatorenal syndrome. $N$ Engl J Med 1965; 272: 895-7.

${ }^{29}$ Ring-Larsen H, Clausen E, Ranek L. Peritoneal dialysis in hyponatriaemia due to liver failure. Scand J Gastroenterol 1972; 8: 33-40.

${ }^{30}$ Wilkinson SP, Weston MJ, Parsons V, Williams R. Dialysis in the treatment of renal failure in patients with liver disease. Clin Nephrol 1977; 8: 287-92.

${ }^{31}$ Clemente C, Bosch J, Rodes J, Arroyo V, Mas A, Maragall S. Functional renal failure and haemorrhagic gastritis associated with endotoxaemia in cirrhosis. Gut 1977; 18: 556-60.

${ }^{32}$ Wilkinson SP, Gazzard BG, Arroyo V, Moodie $\mathrm{H}$, Williams $R$. Relation of renal impairment and haemorrhagic diathesis to endotoxaemia in fulminant hepatic failure. Lancet, 1974; 1: 521-4.

${ }^{33}$ Wilkinson SP, Moodie H, Stamakis JD, Kakkar VV, Williams R. Endotoxaemia and renal failure in cirrhosis and obstructive jaundice. $\mathrm{Br}$ Med J 1976; 2: 1415-8.

${ }^{34}$ Said SI, Hirose T, Kitamura S, Siegel SR. Vasoactive intestinal popypeptide (VIP): Mediator of hemodynamic and respiratory changes in liver cirrhosis? $\mathrm{J}$ Clin Invest 1971; 50: 80A.

${ }^{35}$ Ring-Larsen $\mathrm{H}$, Henriksen JH, Christensen NJ, TrapJensen $\mathbf{J}$. Evidence of enhanced sympathetic nervous activity in patients with cirrhosis. Gastroenterology 1980; 79: 1049 . 